\title{
Energy efficiency, low-carbon energy and economic growth in the Arctic countries - the exporters of hydrocarbons
}

\author{
Andrey Vazim, \\ Department of Economics of Natural Resources \\ National Research Tomsk Polytechnic University \\ Tomsk, Russia \\ E-mail: vazim@tpu.ru,

\section{Elena Lemeshko} \\ Department of Economics of Natural Resources \\ National Research Tomsk Polytechnic University \\ Tomsk, Russia \\ E-mail: lemeshkoel@tpu.ru,
}

\author{
Konstantin Tretyakov \\ Department of Economics of Natural Resources \\ National Research Tomsk Polytechnic University \\ Tomsk, Russia \\ E-mail: tkn1@tpu.ru, \\ Dmitry Khloptsov \\ Department of General and applied Economics \\ National Research Tomsk State University \\ Tomsk, Russia \\ e-mail: d.khloptsov@tokko.tomsk.ru
}

\begin{abstract}
This article studies features of increase of energy efficiency of national economy and reduction of emissions of carbon dioxide for the subarctic countries such as Russia, Canada and Norway. For these countries we define the conditions to achieve sustainable development of indicators of energy intensity and carbon intensity of GDP. Focusing on the dynamics of energy intensity and carbon intensity of GDP, carbon intensity of energy production, in this article the real movement towards the implementation of the program of international organizations for the transition of the economy to a sustainable model of development is analyzed. The examples illustrate both the presence of significant differences between the three countries and the absence of fatality of these differences. In determining the regularities in the article the preference was given to linear models vs non-linear, with the reasons in each case. Greater attention to the progress of these countries may help to understand better the benefits of the transition to sustainable development model and to reduce the demands concerning expanses for such a transition.
\end{abstract}

Keywords—sustainable development; energy intensity; carbon intensity; low-carbon energy

\section{INTRODUCTION}

Russia's support of the idea of sustainable development outlined the direction of improving the competitiveness of the economy by reducing the energy intensity of GDP. Accession to the world trade organization set deadlines and the size of this reduction about $40 \%$ within 2007-2020. However, despite some advances in recent years, this indicator is still almost 2.5 times higher than the world average. However, you might find that the size reduction of the GDP energy intensity in these terms would not be reached. So, the Minister of energy of the
Russian Federation A. V. Novak, at the meeting on 9 April 2014 indicated that the rate of decline in energy intensity of GDP 2011-2013 in relation to 2007 was steadily below the target values. In conditions when the most experts support the view of reducing the energy intensity of the world economy, this gap is represented as the lack of efficiency of the Russian economy. (1) The continuation of the policy of energy conservation will reduce the energy intensity of GDP by 2040 with $45 \%$ compared to 2010 (2\% per year) in the Baseline scenario and two times $(2.3 \%$ per year $)$ in the scenario "Other Asia". The predicted rate of decline in GDP energy intensity will be 2.8-2.1 times lower than achieved in 2000-2008 when they averaged at $5.8 \%$ per year. Baseline scenario - assumes the absence of any significant technological revolutions and breakthroughs. "The other Asia" - a scenario in which the world is facing hard resource constraints at the end of the period. This creates a very favorable opportunity for countriesenergy producers including Russia Federation. (2) However, the drop in hydrocarbon prices was not planned neither in the Baseline scenario nor in the alternative one. Therefore, measures of energy efficiency increase and reduction of the burden on the natural environment have to be slowed down.

In scenario of British Petroleum the results of the policy of energy saving and reduction of $\mathrm{CO} 2$ emissions in the period 1994-2014 and in the period 2014-2035 are compared. (Fig. 1.) (3)

In this figure, there is a noticeable increase of the role of intensive factors in the primary energy production and a sharp increase of the role of reducing carbon dioxide emissions. Among the conditions of the reduction of $\mathrm{CO} 2$ emissions can be defined the activities of both transition to a low-carbon fuel 
for cars and heating buildings, and efforts of changing energy sector of the country.

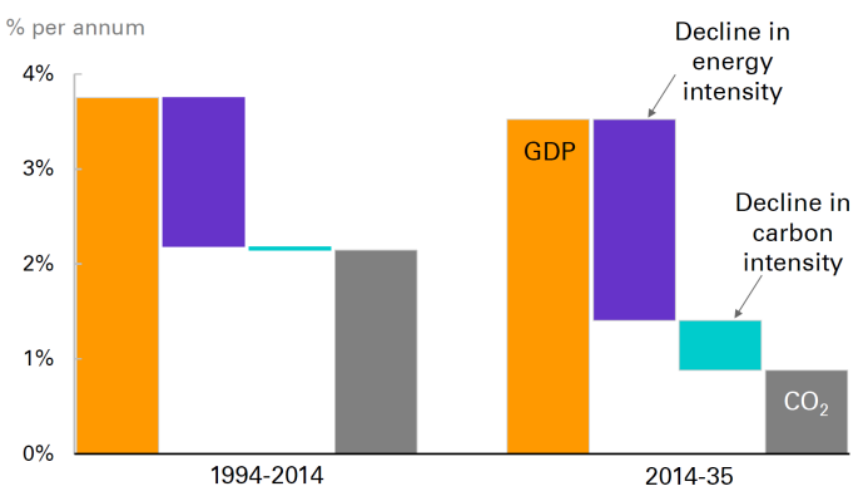

Fig. 1. Decoupling emissions growth from GDP growth.

Next, we consider the dynamics of the indicators that promote sustainable development and stability of the ecological environment: energy efficiency, carbon dioxide emissions in relation to GDP and the consumed energy and the low carbon transition.

\section{IMPROVEMENTS IN ENERGY INTENSITY}

Energy efficiency indicator for the country is often used as an energy intensity of a country, since it is the ratio of the total primary energy supply (TPES) divided by the Gross Domestic Product (GDP) of the country. As presented in Table 1, (4) according to the Organization for Economic Cooperation and Development (hereinafter - OECD) GDP energy intensity in the global economy as a whole from 2000 to 2013 decreases from 0.22 to 0.16 in the total primary energy supply per unit of GDP, calculated as the number of tons of oil equivalent (toe) per unit of GDP (thousand US dollars 2005).

TABLE I. PRODUCTION OF PRIMARY ENERGY TONS OF OIL EQUIVALENT (TOE) PER UNIT OF GDP AT PPP IN 1990, 2000 AND 2013 FOR SELECTED COUNTRIES

\begin{tabular}{|l|l|l|l|l|}
\hline \multirow{2}{*}{\multicolumn{1}{|c|}{ Countries }} & \multicolumn{4}{|c|}{ Years } \\
\cline { 2 - 5 } & $\mathbf{1 9 9 0}$ & $\mathbf{2 0 0 0}$ & $\mathbf{2 0 1 3}$ & $\mathbf{2 0 1 3 / 1 9 9 0}$ \\
\hline Canada & 0.28 & 0.25 & 0.19 & 0.68 \\
\hline Czech Republic & 0.29 & 0.22 & 0.16 & 0.55 \\
\hline Estonia & 0.61 & 0.30 & 0.24 & 0.39 \\
\hline Finland & 0.25 & 0.22 & 0.19 & 0.76 \\
\hline France & 0.16 & 0.14 & 0.12 & 0.75 \\
\hline Germany & 0.17 & 0.13 & 0.11 & 0.65 \\
\hline Iceland & 0.34 & 0.36 & 0.48 & 1.41 \\
\hline Japan & 0.13 & 0.14 & 0.11 & 0.85 \\
\hline Norway & 0.15 & 0.13 & 0.13 & 0.87 \\
\hline Poland & 0.33 & 0.20 & 0.14 & 0.42 \\
\hline Slovakia & 0.34 & 0.25 & 0.15 & 0.44 \\
\hline Sweden & 0.22 & 0.17 & 0.14 & 0.64 \\
\hline United Kingdom & 0.16 & 0.12 & 0.09 & 0.56 \\
\hline USA & 0.24 & 0.20 & 0.15 & 0.63 \\
\hline EU-28 & 0.17 & 0.14 & 0.11 & 0.65 \\
\hline OECD & 0.19 & 0.16 & 0.13 & 0.68 \\
\hline Brazil & 0.13 & 0.11 & 0.11 & 0.85 \\
\hline China & 0.70 & 0.29 & 0.22 & 0.31 \\
\hline India & 0.30 & 0.19 & 0.13 & 0.43 \\
\hline Russian Federation & 0.47 & 0.49 & 0.33 & 0.70 \\
\hline The world & 0.22 & 0.19 & 0.16 & 0.73 \\
\hline
\end{tabular}

The energy intensity of Russia's GDP in the same period decreases from 0.49 to 0.33 . In Canada - from 0.25 to 0.19 . In Norway it has not changed -0.13 . For comparison: in China, the decline from 0.29 to 0.22 ; USA - from 0.20 to 0.15 ; in the European Union ( 28 countries) - from 0.14 to 0.11 ; OECD countries - from 0.16 to 0.13 ; in Japan - from 0.14 to 0.11 .

It should be noted that the GDP energy intensity decrease occurred not in all countries. So in 2013 compared to 1990 in Norway this figure was almost unchanged (from 0.87), in Brazil and Japan it have changed at about the level of Norway (0.85), while in Iceland it even increased by $41 \%$ ! In Russia $(0.70)$ and Canada $(0,68)$ the dynamics of reduction of energy intensity was better than in the whole world (0.73) though worse than in the countries members of the OECD (0.68) and the EU-28 - 0.65. (5)

The absolute leader of the reduction of energy intensity of GDP is China - 0.31. The second most significant country who have achieved success should be considered India (0.43). Then follow the former socialist countries - Estonia (0.39 in), Poland (0.42), Slovakia (0.44). However, these countries are not comparable with Russia neither the population nor the territory, nor in the socio-economic policy (Eastern European members of the EU indulgently look at the sharp decline in the production and emigration of young specialists from the country). (6) Therefore, by choosing the strategy of reduction of primary energy consumption, it is necessary to consider the possible reserves of energy efficiency increase in industries.

\section{CARBON DIOXIDE EMISSIONS}

Addition to energy efficiency may be the reduction of greenhouse gases the main of which is carbon dioxide $(\mathrm{CO} 2)$. $\mathrm{CO} 2$ emissions depend on energy intensity (the amount of energy used per unit of GDP) and carbon intensity or the carbon content of the energy mix (carbon per unit of energy). Below is the table 2, which lists the carbon emissions for three countries: Russia Federation, Norway and Canada. (7)

TABLE II. CARBon Dioxide EMISSIONS, MT OF $\mathrm{CO}_{2}$

\begin{tabular}{|l|c|c|c|c|c|}
\hline \multirow{2}{*}{ Countries } & \multicolumn{5}{|c|}{ Years } \\
\cline { 2 - 6 } & $\mathbf{1 9 8 5}$ & $\mathbf{2 0 0 0}$ & $\mathbf{2 0 0 5}$ & $\mathbf{2 0 1 0}$ & $\mathbf{2 0 1 4}$ \\
\hline $\begin{array}{l}\text { Russian } \\
\text { Federation }\end{array}$ & 2284.5 & 1557.9 & 1594.5 & 1646.1 & 1657.2 \\
\hline Canada & 450.6 & 593.6 & 636.0 & 611.9 & 620.5 \\
\hline Norway & 34.5 & 41.2 & 43.5 & 44.2 & 44.2 \\
\hline
\end{tabular}

From the figures presented in the table, we see that in the period 1985-2000 Russia Federation has reduced emissions by $32.8 \%$, while Canada increased by $31.7 \%$ and Norway - by $19.4 \%$. In the period 2000-2014 Russia Federation increased by $6.4 \%$, Canada- $4.5 \%$, Norway - by $7.3 \%$. Thus, the success of Russia in this regard is very significant.

The following figure (Fig. 2.) characterizes the dependence of the emissions of carbon dioxide from the Gross Domestic Product (GDP) is expressed in terms of real Purchasing Power Parity (PPP) at 2005 prices (briefly - CO2/GDP PPP), measured in $\mathrm{kg}$ of carbon dioxide per USD at 2005 prices.

The analysis of this figure allows to draw the following conclusions. First of all, we see that the rate of CO2/GDP PPP 
for the three countries differs significantly. Thus, in 2014 the rate of Canada exceeded the Norwegian by almost three times (186\%), in turn, lagging behind Russia almost twice $(57 \%)$. It shows considerable variation in the structure of the economies of selected countries. Russia Federation has considerable potential for reducing carbon dioxide emissions. Russia's lag from Norway of 5 times seem insurmountable, if not previous achievements in the reduction of this indicator earlier. (8)

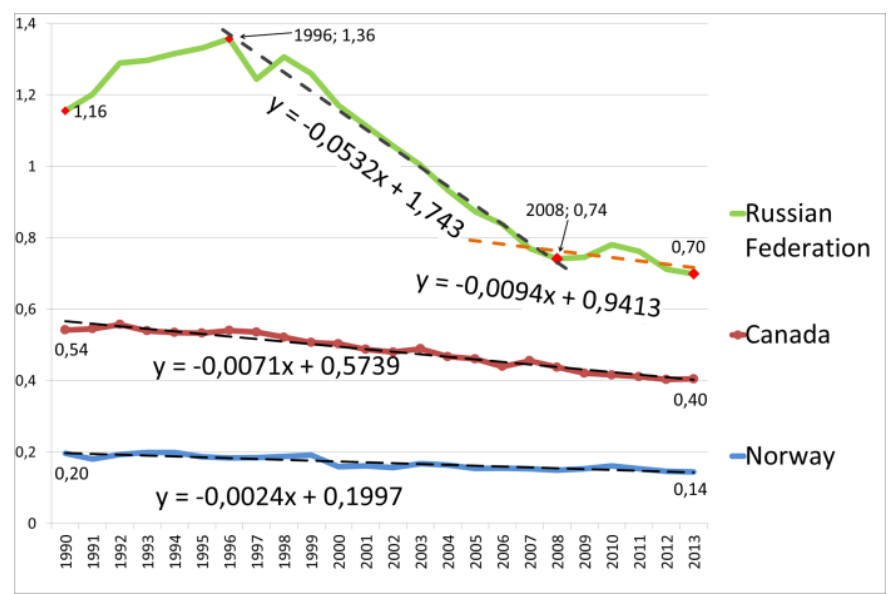

Fig. 2. CO2/ GDP PPP Carbon Dioxide Emissions / Gross Domestic Product by Purchasing Power Parity (t CO2/2005 USD) for Russian Federation, Canada, Norway 1985-2014 гг.

So, while Russia Federation presents wavelike dynamics, Canada (1) Norway (2) have stable dynamics of reduction, respectively:

$$
y=-0.0071 x+0.5739
$$

and

$$
y=-0.0024 x+0.1997
$$

The curve CO2/GDP PPP of Russia Federation has three areas. In the initial period (up to 1996) there has been an increase from 1.16 to $1.36 \mathrm{~kg} \mathrm{CO} 2 / 2005$ USD. Then there was a sharp fracture, deviated temporarily in 1998 due to the economic crisis. Russia's achievements in this period: 1.36 (1996) to 0.74 (2008). The degree of reduction of the indicator:

$$
y=-0.0532 x+1.743
$$

However, the crisis of 2008 has suspended the reduction capacity of the carbon dioxide emissions to GDP. Low rate:

$$
y=-0.0094 x+0.9413
$$

Comparing equations (1) and equation (4) gives us the following answer: when you save the conditions, Russia Federation will overtake Canada through 160 years.
However, it should be noted that this indicator strongly depends on the high amplitude dynamics of Russia's GDP. Therefore, we expect that the structural reforms in the economy accelerate the convergence of Russia Federation and Canada. The basis for such confidence is the dynamics of the following indicators - emissions of carbon dioxide per unit of energy consumed in tones of oil equivalent (toe).

An additional condition of our confidence are the indicators of the Energy strategy of Russia Federation for the period until 2035, which states that by 2035, the share of energy-intensive industries will be 1.5 times reduced. Thus it will increase the energy consumption only by $25-27 \%$ with a target economy growth of 2.5 times. (9)

\section{CARBON INTENSITY OF ENERGY CONSUMPTION}

Power consumption can be expressed in different units (kilowatt-hours, joules, tons of oil equivalent, etc.). At the same time, this should indicate the distinction between primary products such as crude oil, coal, and natural gas. All energy products which are produced from the primary are called secondary.

Especially noted should be the production of electricity. Thus, the primary source will be the electricity that is produced from natural sources, such as the energy of falling water, geothermal reservoirs, the energy of the Sun for solar panels. Secondary electricity is the one generated from burning coal, oil, gas, and other mined mineral resources.

Therefore, for the purposes of this article, we will take into account only the amount of primary energy converted into "metric tons of oil equivalent".

We should indicate that Russia Federation is not yet a leader in the ratio of $\mathrm{CO} 2$ emissions per unit of energy consumed in tones of oil equivalent (fig. 3).

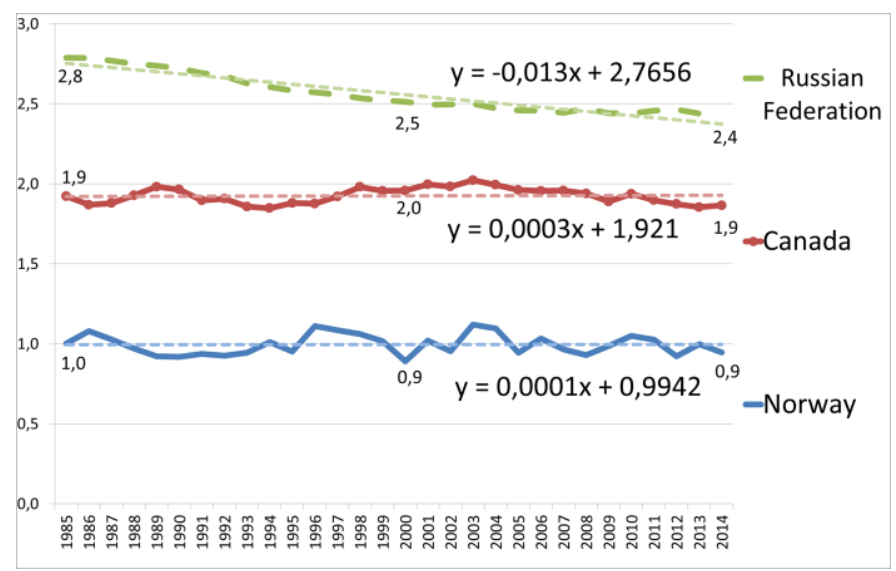

Fig. 3. CO2/TPES Carbon Dioxide Emissions / Consumption Primary Energy (t CO2/toe) for Russian Federation, Canada, Norway 1985-2014 гг.

When examining the data presented in Fig. 3. The following can be noted. The biggest carbon dioxide emissions per 1 toe of energy consumption Russia Federation has and in 2014 it reached a value of $2.4 \mathrm{t} \mathrm{CO} 2 /$ toe. Canada - 1.9, Norway - 0.9. On this indicator Russia Federation has surpassed Canada by $30 \%$, and Norway - $157 \%$, while Canada topped Norway by $97 \%$. It should be noted that Russia 
Federation (5) has such a feature, as the downward trend of the ratio:

$$
y=-0.013 x+2.7656
$$

Whereas Norway (6) Canada (7) have a positive trend:

$$
y=-0.0001 x+0.9942
$$

and

$$
y=-0.0003 x+1.921
$$

The following means that under the given conditions Russia according to the level of $\mathrm{CO} 2$ emissions for consumed energy can reach Canada in 53 years and Norway in 135 years.

\section{LOW-CARBON ENERGY SOURCES}

Current anthropogenic impact is $45-47$ bln. tons $\mathrm{CO} 2$ equivalent per year. The energy sector provides about 30 bln. tons $\mathrm{CO} 2$ eq. / year. Such a transition should ensure the $50-80 \%$ reduction in global greenhouse gas emissions by 2050 . (10)

The Bridge Scenario from The International Energy Agency puts a brake on growth in coal use within the next five years: oil demand rises to $95 \mathrm{mb} / \mathrm{d}$ by around 2020 and then plateaus, while coal demand peaks before 2020. Total emissions of GHG, energy-related will reach a peak around 2020. Indicators of energy intensity of the world economy and carbon intensity of electricity production will improve by $40 \%$ by 2030 . (11)

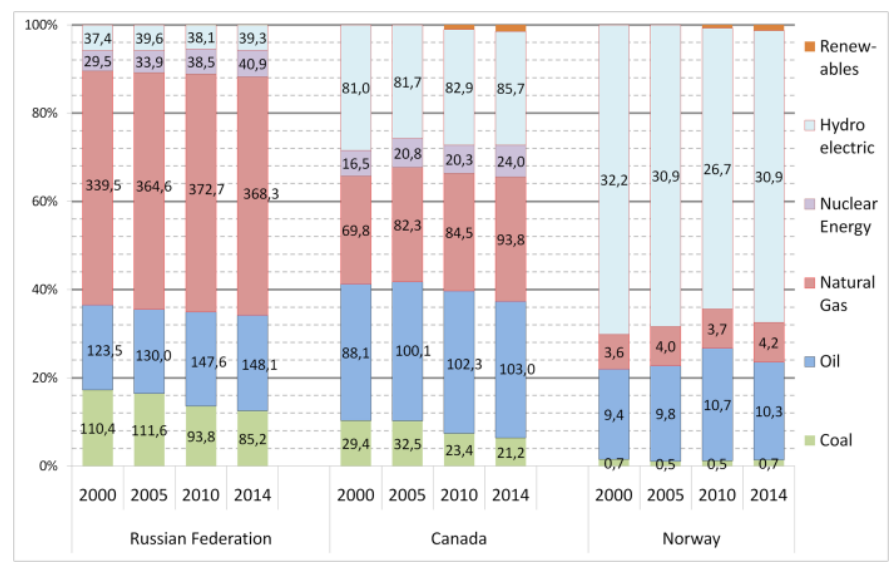

Fig. 4. The structure of primary energy consumption in the Russian Federation, Canada and Norway in 2000-2014, Mln toe

Below we examine the structure of energy consumption for various fuel types in the three arctic countries from 2000 to 2014. (12) Building of the Figure 4 has the following features. For clarity, the diagram has been selected, where each type of fuel consumption is expressed as a fraction of total consumption volume. In addition, for each cell chart the volumes of fuel consumption have been specified in absolute units - millions of tons of oil equivalent.
In the presented figure 4, we note the following. In 20002014 in Russia the consumption of natural gas has the largest share - 53-54\%. In Norway most goes to the hydropower 70.2-66.2\%. But Canada has a more uniform structure: oil about $30.9-31.0 \%$ (32.3\% in 2010); natural gas is $24.5-28.2$ per cent; hydropower - 28.4- $25.8 \%$. Thus, with oil maintaining the leadership, the second ranked natural gas, then hydro-power.

Another aspect to note is the appearance in reports of renewable energy sources since 2010 . Their share is highest in Canada: in 2010 - 1,042\%, in 2014 - 1,462\%. Second comes Norway with 0.718 and $1.263 \%$ respectively. Russia is on the third place -0.014 and $0.017 \%$. When viewed in absolute terms, Canada is still in the lead: 3.3 (2010), 4.9 million toe (2014). Accordingly, in Norway - 0.3 and 0.6 million toe; in Russia by 0.1 million toe. This ratio of renewable energy consumption can be attributed to each type of energy source price ratio after the application of measures of state support for the industry and the proximity to the innovation centers. (13) In addition, the feature of Canada is that being exporter of hydrocarbons in the United States (eastern regions of Canada), it re-imports large quantity of it from the United States (western areas), while remaining a net exporter. Such situation (the importer's position) encourages the introduction of alternative sources of energy like at all importers of oil and gas. Norway and Russia Federation are the "regular" energy exporters. At the same time, Norway has the following feature - a high ratio of land areas suitable for wind energy (coastal strip of ice-free in the seas) to the area of the country. Russia and Canada have no such feature.

We will begin studying a problem of development of lowcarbon power with coal and oil as high-carbon power sources. Though natural gas incorporates carbon, but it has a mass fraction of the carbon dioxide formed when burning that is many times less than such size in oil and, especially, in coal.

The leader in a share of a contribution of low-carbon power to power balance of the country is Norway - 78.0 (2010) and $76.4 \%$ (2014). On the second place is Russia Federation -63.5 and $65.8 \%$ respectively. Canada is the third -58.7 and $62.7 \%$ respectively. But it is necessary to note that the share of lowcarbon power grows in Russia Federation and Canada, while in Norway it falls.

However it should be noted that Russia and Canada can change places in this rating. It is because of the fact that the coal share in power balance of the country in Russia is higher than in Canada. In Russia - 17.2 (2010) and 12.5\% (2014) and in Canada -10.3 and $6.4 \%$ respectively.

\section{REFERENCES}

[1] M. Tsibulnikova, O. Kupriyanova, A. Strelnikova, "Economic assessment of environmental impact in the course of oil field development and production," IOP Conference Series: Earth and Environmental Science, 2015, vol. 27 [Problems of Geology and Subsurface Development], URL: http://dx.doi.org/10.1088/1755-1315/27/1/012076

[2] Forecast of development of the world energy and Russia until 2040, pp. 123, URL: http://www.eriras.ru/files/forecast_2040.pdf

[3] BP Energy Outlook 2016 edition p. 48. URL: http://www.bp.com/content/dam/bp/pdf/energy-economics/energyoutlook-2016/bp-energy-outlook-2016.pdf 
[4] OECD.org.statistics. Total primary energy supply per unit of GDP URL: http://dx.doi.org/10.1787/888933028045

[5] International Energy Agency-Statistics-Statistics Search-Report. URL: http://www.iea.org/statistics/statisticssearch/report/?country=RUSSIA\& product=indicators\&year $=2013$

[6] E. Matugina, O. Pogharnitskaya, K. Petrova, A. Strelnikova, "Intensive use of energy resources regarding sustainable cities", IOP Conference Series: Earth and Environmental Science, 2015, vol. 27, 4p.

[7] BP Statistical Review of World Energy 2015. URL: http://www.bp.com/content/dam/bp/excel/energy-economics/statisticalreview-2015/bp-statistical-review-of-world-energy-2015-workbook.xlsx

[8] M. Tsibulnikova, D. Salata, A. Ospanov, A. Strelnikova, "The comparative analysis of payments for negative environmental impact in Russia and Kazakhstan," IOP Conference Series: Earth and Environmental Science, 2015, vol. 27 [Problems of Geology and Subsurface Development], URL: http://dx.doi.org/10.1088/1755-1315/27/1/012077

[9] Russia's Energy Strategy for the period until 2035 p. 8. URL: http://ac.gov.ru/files/content/1578/11-02-14-energostrategy-2035pdf.pdf

[10] Flow chart of world energy by 2050 , URL: http://old.rgo.ru/wp-content/uploads/2011/02/Kartina-mira.pdf

[11] The International Energy Agency Energy and Climate Change. World, Energy Outlook Special Report, pp. 67, URL: http://www.iea.org/publications/freepublications/publication/WEO2015 SpecialReportonEnergyandClimateChange.pdf

[12] Primary Consumption by Fuel, BP Statistical Review of World Energy 2015 full report, . URL: http://www.bp.com/statisticalreview

[13] V. Konovalov, O. Pogharnitskaya, A. Rostovshchikova, I. Matveenko "Potential of renewable and alternative energy sources", IOP Conference Series: Earth and Environmental Science, 2015, Vol. 27, 5p. 
